\title{
Determination of photochemically available iron in ambient aerosols
}

\author{
Ronald L. Siefert, Samuel M. Webb, and Michael R. Hoffmann \\ Environmental Engineermn Science, W. M. Keck Laboratories, California Institute of Technology, Pasadena
}

\begin{abstract}
Experiments to determine the concentration of photochemically available $\mathrm{Fe}$ in ambient aerosol samples were carried out using a novel photochemical extraction procedure. Ambient aerosol samples, which were collected on Teflon filters, were suspended in an aqueous solution within a photochemical reactor and irradiated. Under these conditions, which were favorable to the photochemical weathering of acrosol particles, the relative amount of $\mathrm{Fe}(\mathrm{II})_{\mathrm{aq}}$ to $\mathrm{Fe}_{\text {total }}$ was shown to increase. The extent and rate of $\mathrm{Fe}(\mathrm{II})_{\text {aq }}$ photoproduction was used to characterize the Fe in aerosol samples collected from Whiteface Mountain, New York, Pasadena, California, San Nicholas Island, California, and Yosemite National Park, California. Photochemically available Fe concentrations found ranged from $<4 \mathrm{ng} \mathrm{m}^{-3}\left(0.07\right.$ nmole $\left.\mathrm{m}^{-3}\right)$ to $308 \mathrm{ng} \mathrm{m}^{-3}$ $\left(5.52\right.$ nmole $\left.\mathrm{m}^{-3}\right), \mathrm{Fe}_{\text {total }}$ concentrations ranged from $10 \mathrm{ng} \mathrm{m}^{-3}\left(0.18 \mathrm{nmole} \mathrm{m}{ }^{-3}\right)$ to $3400 \mathrm{ng} \mathrm{m}^{-3}\left(61 \mathrm{nmole}^{-3}\right)$, and the percentage of photochemically available $\mathrm{Fe}$ to $\mathrm{Fe}_{\text {total }}$ ranged from $2.8 \%$ to $100 \%$. Aerosol samples were also collected during biomass burning events in southern California; these samples showed insignificant changes in the photochemically available Fe (compared to nonbiomass burning samples) in conjunction with large increases of $\mathrm{Fe}_{\text {total }}$. Calculations based on these experiments also provide further evidence that redox reactions of $\mathrm{Fe}$ in cloudwater could be an important in situ source of oxidants $\left(\mathrm{OH}, \mathrm{HO}_{2}^{-} / \mathrm{O}_{2}^{-}\right)$. The estimated oxidant production rate in cloudwater based on these experiments is between 0 and $60 \mathrm{nM} \mathrm{s}^{-1}$, with an average value of $16 \mathrm{nM}$ $\mathrm{s}^{-1}$. This estimated in situ oxidant production rate due to Fe chemistry is approximately equal to previous estimates of the oxidant flux to cloudwater from the gas phase.
\end{abstract}

\section{Introduction}

Iron (Fe), which is one of the most abundant elements in the Earth's crust, is present primarily as $\mathrm{Fe}$ (II) and $\mathrm{Fe}$ (III) forms [Taylor and McLennan, 1985]. Particulate Fe is transferred to the atmosphere by wind, volcanic activity, and through anthropogenic sources [Cass and McRae, 1983; Seinfeld, 1986; Gomes and Gillette, 1993]. Total Fe concentrations in tropospheric aerosols range from 0.6 to $4160 \mathrm{ng} \mathrm{m}^{-3}$ in remote areas, 55 to $14500 \mathrm{ng} \mathrm{m}^{-3}$ in rural areas, and 21 to $32820 \mathrm{ng} \mathrm{m}^{-3}$ in urban areas [Schroeder et al., 1987], and cloudwater concentrations range from 0.4 to $424 \mu \mathrm{M}$ [Waldman et al., 1982; Munger et al., 1983; Jacob et al., 1985; Fuzzi et al., 1988; Behra and Sigg, 1990].

Atmospheric particulates are the source of Fe and other transition metals to cloudwater. Ambient aerosol particles are incorporated into cloudwater as condensation nuclei or are dynamically captured by impaction or differential settling. These processes result in a suspension of particles and dissolved species in cloudwater derived from aerosol particles. A fraction of the total Fe present in aerosol can dissolve into solution [Zhu et al., 1992, 1993; Zhuang et al., 1992a] along with other water-soluble species. Once in the droplet, Fe can participate in a variety of homogeneous and heterogeneous electron-transfer reactions. The specific mineral form of the particulate $\mathrm{Fe}$ is important to both the dissolution rate and the photoreactivity of the particles [Pehkonen et al., 1993, 1995].

$\mathrm{Fe}(\mathrm{III}) / \mathrm{Fe}(\mathrm{II})$ redox couples are important mediators of

Copyright 1996 by the American Geophysical Union.

Paper number 96JD00857.

0148-0227/96/96JD-00857\$09.00 charge-transfer reactions in natural waters [Schwarzenbach et al., 1993]. Fe(III)-carboxylate complexes have been shown to undergo photoassisted redox reactions where the $\mathrm{Fe}$ (III) is reduced to $\mathrm{Fe}(\mathrm{II})$ and the complexed organic anion is oxidized [Zuo and Hoigné, 1992; Faust and Zepp, 1993; Pehkonen et al., 1993, 1995]. The Fe(III) species can either be aqueous Fe(III) complexes or surficial Fe(III) complexes associated with an Fe-oxyhydroxy polymorph (e.g., goethite, hematite, amorphous Fe-oxyhydroxide) [Pehkonen et al., 1993]. Pehkonen et al. [1993] have shown that $\mathrm{Fe}$ (III)-carboxylate photochemistry can be an important pathway for the degradation of carboxylic acids in the atmosphere. The degradation products include lower chain carboxylic acids and hydrogen peroxide $\left(\mathrm{H}_{2} \mathrm{O}_{2}\right)$ [Zuo and Hoigné, 1992; Pehkonen et al., 1993; Siefert et al., 1994]. In previous studies it has been assumed that the primary source of atmospheric $\mathrm{H}_{2} \mathrm{O}_{2}$ was controlled by gas phase reactions [Gunz and Hoffmann, 1990; Sakugawa et al., 1990; Thompson, 1992]. However, Zuo and Hoigné [1992] have shown that the photolysis of $\mathrm{Fe}$ (III)-oxalate complexes may be an important source of $\mathrm{H}_{2} \mathrm{O}_{2}$ in cloudwater. In addition, this pathway for the heterogeneous production of $\mathrm{H}_{2} \mathrm{O}_{2}$ may be an important factor in regulation of the oxidation capacity of the atmosphere.

The availability of Fe also affects S(IV)/S(VI) chemistry. Aqueous $\mathrm{SO}_{3}^{2-}$, can react with $\mathrm{Fe}(\mathrm{III})_{\mathrm{aq}}$ in oxic waters to yield $\mathrm{Fe}(\mathrm{II})_{\mathrm{aq}}, \mathrm{SO}_{4}^{2-}, \mathrm{HSO}_{\mathrm{t}}^{-}$, and $\mathrm{H}_{2} \mathrm{O}_{2}$ via the formation of $\mathrm{SO}_{3}^{--}$, $\mathrm{SO}_{4}^{-*}, \mathrm{SO}_{5}^{--}$, and $\mathrm{HO}_{2}^{-}$[Jacob et al., 1986; Breytenbach et al., 1994]. Iron can also indirectly oxidize S(IV), through the production of $\mathrm{H}_{2} \mathrm{O}_{2}$ by the photolysis of the $\mathrm{Fe}$ (III)-oxalate complex and the subsequent oxidation of $\mathrm{S}(\mathrm{IV})$ by $\mathrm{H}_{2} \mathrm{O}_{2}[$ Hoff- 


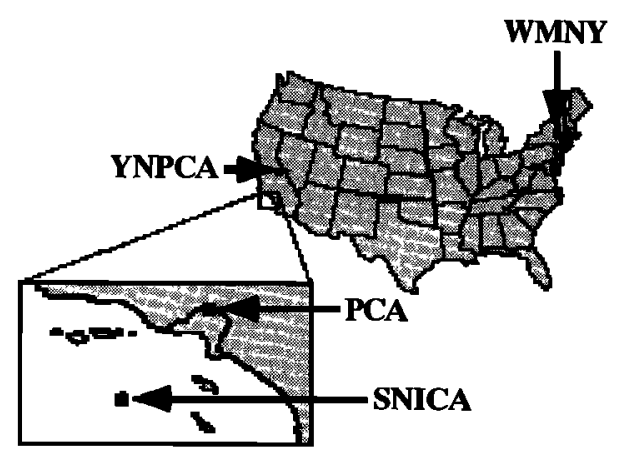

Figure 1. Ambient aerosol collection sites: Whiteface Mountain, New York (WMNY); Yosemite National Park, California (YNPCA); San Nicholas Island, California (SNICA); Pasadena, California (PCA).

mann and Edwards, 1975; McArdle and Hoffmann, 1983]. This indirect $\mathrm{S}(\mathrm{IV})$ mechanism may be very important since $\mathrm{H}_{2} \mathrm{O}_{2}$ is the principal oxidant of S(IV) to S(VI) in the atmosphere from pH 2 to 4 [Hoffmann and Boyce, 1983; Jacob and Hoffmann, 1983; Hoffmann and Jacob, 1984]. Iron is also a limiting nutrient to primary phytoplankton growth in certain regions of the open ocean [Martin and Gordon, 1988; Ditullio et al., 1993; Kolber et al., 1994; Martin et al., 1994; Price et al., 1994]; and the speciation of $\mathrm{Fe}$ is critical to the rate of Fe uptake by phytoplankton.

Investigation of cloudwater photochemistry has been centered around the use of ambient fogwater or cloudwater [Faust and Allen, 1992, 1993; Zuo and Hoigné, 1992], or synthetic Fe oxide particles [Pehkonen et al., 1993, 1995] in laboratory experiments. Several investigators have examined the speciation of Fe in ambient aerosols by determining (1) the concentration of $\mathrm{Fe}(\mathrm{II})$ [Zhuang et al., 1992; Zhu et al., 1993], (2) the concentration of soluble Fe [Zhu et al., 1993; Spokes et al., 1994], and (3) the mineral form of the Fe through Mossbauer spectroscopy [Kopcewicz and Kopcewicz, 1991, 1992]. These procedures measured the concentration of $\mathrm{Fe}$ in specific phases but did not directly address the dynamic time-dependent reactivity of the Fe.

Similar studies have focused on the photoreactivity of suspended ambient aerosol samples in aqueous solution [ $Z h u$ et al., 1993; Siefert et al., 1994]. For example, Zhu et al. [1993] explored the photolysis of aqueous Fe solutions, that were leached from marine aerosol samples. They chose their experimental conditions to simulate haze aerosol solutions with an ionic strength equal to $0.1 \mathrm{M}$ and a $p \mathrm{H}$ equal to 1 . Their experiments showed a high level of photoreactivity of the $\mathrm{Fe}$ leached from marine aerosol samples in the presence of various inorganic anions. However, the filters leached by Zhu et al. [1993] may have contained a significant amount of photochemically available Fe. For example, Pehkonen et al. [1993] showed that the photoreduction of Fe also occurs with particulate $\mathrm{Fe}$ (III), thus the experimental methods used by Zhu et al. [1993] may not represent the total photoreactivity of $\mathrm{Fe}$ in aerosol samples.

Quantification of the amount of photochemically available $\mathrm{Fe}$ in aerosol samples is important, since it should account for all of the species of Fe that may take part in Fe-induced photochemistry in the atmosphere. In this paper we describe a series of experiments that were carried out to determine the amount of photochemically available $\mathrm{Fe}\left(\mathrm{Fe}_{\mathrm{PA}, \mathrm{total}}\right)$, soluble $\mathrm{Fe}(\mathrm{II})\left(\mathrm{Fe}(\mathrm{II})_{\text {soluble }}\right)$, and total $\mathrm{Fe}\left(\mathrm{Fe}_{\text {total }}\right)$ present in a variety of ambient aerosol samples.

\section{Methods}

\section{Ambient Aerosol Collection}

Ambient aerosol was collected on 47-mm Gelman Zefluor PTFE filters with a pore size of $1 \mu \mathrm{m}$. Collection sites were located at Whiteface Mountain, New York (WMNY), Yosemite National Park, California (YNPCA), San Nicholas Island, California, (SNICA), and Pasadena, California (PCA) (Figure 1). These locations were chosen to provide several diverse sampling regions. The sites at YNPCA and WMNY provided two continental environments with varying weather patterns. PCA provided a polluted urban atmosphere and SNICA provided a coastal island environment. A volumetric flow rate of $10 \mathrm{~L} \mathrm{~min}^{-1}$ through each filter was maintained with a critical orifice. A set of two to nine filters were used for each collection. Filters, polycarbonate filter holders, and labware were cleaned rigorously before use by following similar procedures as outlined by Patterson and Settle [1976]. The Gelman Zefluor filters were placed in a warm $10 \%$ HF bath for 24 hours followed by a warm $10 \% \mathrm{HNO}_{3}$ bath, also for 24 hours. The filters were rinsed with water between the baths and after the final bath (ultrapure acids from Seastar Chemicals, Sidney, British Columbia, Canada, and 18.2 M $\Omega$-cm Milli-Q UV water were used for all steps). The filter holders were placed in a warm $5 \% \mathrm{HNO}_{3}$ bath (reagent grade $\mathrm{HNO}_{3}$ ) for 24 hours followed by a warm $1 \% \mathrm{HNO}_{3}$ (Seastar Chemicals, ultrapure $\mathrm{HNO}_{3}$ ) bath. The filter holders were rinsed with water between the baths, and also after the second bath. After collection of aerosol samples, the filters were stored in the dark at $21^{\circ} \mathrm{C}$ and a relative humidity of $50 \%$ for 24 hours and then weighed (these were the same conditions used to preweigh the filters). This weighing technique is similar to the one followed by Ligocki et al. [1993]. After weighing, the samples were stored in the dark at $4^{\circ} \mathrm{C}$, for periods ranging from 2 months to 2 years prior to use in photochemical experiments.

\section{Simulated Cloudwater, Experimental Procedures}

The 47-mm-diameter filter used to collect the ambient aerosol sample was securely placed in an all-Teflon ${ }^{\mathrm{TM}}$ photochemical reactor vessel (Figure 2). The vessel was designed in order to allow the entire filter surface to be irradiated during the experiments. The reactor vessel was then placed in a box designed to minimize the irradiation of the reactor vessel from ambient light. An aqueous solution of $500 \mu \mathrm{M}$ formate/formic

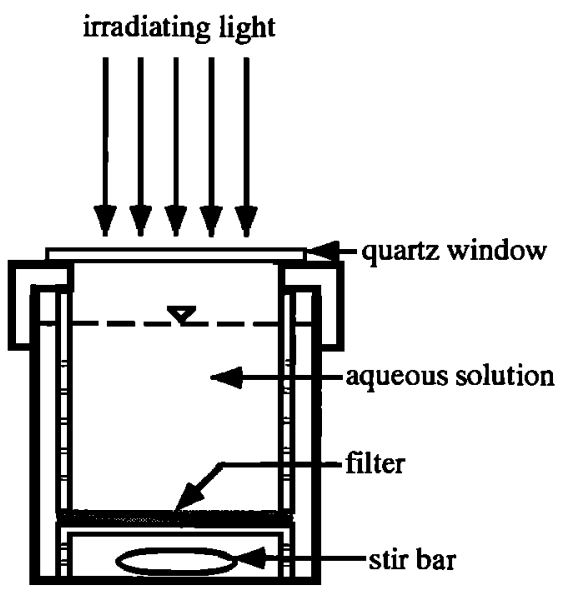

Figure 2. Reactor vessel used in photochemically available Fe experiments. 
acid (for simplicity, formate, the anion name of the acid, will be used) at a $p \mathbf{H}$ of $4.25 \pm 0.05$ was then added to the vessel. The $p \mathrm{H}$ of the formate solution was measured using a combination electrode (FUTURA plus combination electrode, Beckman Instruments, Inc.) with a portable $p \mathrm{H}$ meter (PHM 80, Radiometer America, Inc.), and using a two-point calibration (with $p \mathrm{H} 4$ and $p \mathrm{H} 7$ buffer solutions). Even though the $p \mathrm{H}$ values in cloudwater vary over a wide range depending on meteorological conditions, anthropogenic sources, liquid water content, and other parameters, a $p \mathbf{H}$ of 4.25 was chosen as a representative cloudwater $p \mathrm{H}$ for these experiments. At a $p \mathbf{H}$ of 4.25 the oxidation of $\mathrm{Fe}(\mathrm{II})_{\mathrm{aq}}$ by oxygen is relatively slow with a calculated half-life of $\mathrm{Fe}(\mathrm{II})_{\text {aq }}$ of 113 hours assuming $\mathrm{P}_{\mathrm{O}_{2}}=$ $0.21 \mathrm{~atm}$ [Wehrli, 1990]. Formate was chosen as the buffer since it is commonly the most abundant carboxylate species found in cloudwater [Munger, 1989; Munger et al., 1989; Kawamura and Kaplan, 1991; Zuo and Hoigné, 1992; Erel et al., 1993]. Formate concentrations in fogwater and cloudwater have been found to vary between 12 and $75.6 \mu \mathrm{M}$ [Munger, 1989; Munger et al., 1989; Erel et al., 1993]. The higher concentrations of formate $(500 \mu \mathrm{M})$ in these experiments was used to increase the buffering capacity of the solution and to maintain a constant ionic strength $(I=310 \mu \mathrm{M})$. Overall, the experiments were designed to have conditions similar to observed cloudwater conditions.

Rigorous procedures were employed to minimize Fe contamination. The reactor vessel was cleaned in a warm $5 \%$ $\mathrm{HNO}_{3}$ bath for several hours and rinsed with $18.2 \mathrm{M} \Omega-\mathrm{cm}$ Milli-Q water before use. Control experiments were carried out periodically with a clean filter to determine the level of $\mathrm{Fe}$ contamination. In all cases no detectable $\mathrm{Fe}$ (II) was produced. A quartz window was placed on top of the vessel to prevent evaporation. Before the vessel was irradiated, a $2-\mathrm{mL}$ aliquot was taken to record the initial $p \mathbf{H}$ and initial $\mathrm{Fe}(\mathrm{II})_{\text {aq }}$ concentration. A 450-W xenon lamp (Oriel) with a 320-nm cutoff filter and an IR filter was used as the light source. The photon flux between 320 and $390 \mathrm{~nm}$, which was measured using a chemical actinometer, Aberchrome 540 [Heller and Langan, 1981], was $I_{0}=1.5 \times 10^{1.5}$ photons $\mathrm{cm}^{-2} \mathrm{~s}^{-1}$ in all experiments (except where noted). This photon flux is about an order of magnitude lower then natural sunlight over the same wavelength range. For example, natural sunlight with a zenith angle of $30^{\circ}$ has a photon flux between 320 and $390 \mathrm{~nm}$ of $1.3 \times 10^{16}$ photons $\mathrm{cm}^{-2} \mathrm{~s}^{-1}$ [Demerjian et al., 1980]. The reactor vesse] had a vertical window with an area of $13.4 \mathrm{~cm}^{2}$. The reactor vessel was kept at a temperature of $28^{\circ} \mathrm{C}$, via fan-driven air cooling. $\mathrm{Fe}(\mathrm{III})_{\mathrm{dq}}$ was measured colorimetrically with ferrozine [Stookey, 1970; Carter, 1971]. All aliquots were filtered through a $0.2-\mu \mathrm{M}$ cellulose acetate syringe filter before analysis. Aliquots taken for total metal analysis were not filtered.

At the end of the photochemical experiment, when $\mathrm{Fe}(\mathrm{II})_{\mathrm{aq}}$ concentrations had reached a steady state, $\mathrm{HCl}$ was added to the remaining solution in the reactor vessel until a $p \mathrm{H}$ of 1 was reached. The solution was then stirred overnight to extract any remaining Fe from the filter. An aliquot of this solution was removed and analyzed for total metals. The filter was then removed from the reactor vessel and weighed (after equilibrating to $21^{\circ} \mathrm{C}$ and a relative humidity of $50 \%$ ) to determine the mass of particulates suspended or dissolved into solution during irradiation. A strong mineral-acid digestion procedure (using ultrapure $\mathrm{HF}, \mathrm{HNO}_{3}$, and $\mathrm{HCl}$ acids from Seastar Chemicals) was used to dissolve the remaining particulates on the filter for total metal measurements. The procedure involved using a ceramic knife and a polycarbonate cutting board to take $a \approx 1 / 4$ slice from the filter. The filter slice was then weighed and compared to the total filter mass to determine the filter slice fraction, which was used later to calculate the total concentration on the filter. The filter slice was then placed in 2 $\mathrm{g}$ of concentrated $\mathrm{HF}$ and $2 \mathrm{~g}$ of concentrated $\mathrm{HNO}_{3}$. This was followed by vigorous shaking of the solution and filter slice overnight. After the extraction the filter slice was removed and the solution was evaporated to dryness. The resulting residue was then digested in $10 \mathrm{~g}$ of $10 \% \mathrm{HCl}$. Concentrations of iron were measured using ICP-MS (Perkin Elmer-SCIEX Elan 5000 ). These concentrations (along with the volume of solution in the digestion and the volume of air sampled) were then used to calculate the atmospheric concentrations of $\mathrm{Fe}_{\text {tutal. }}$.

\section{Pseudo-First-Order Kinetic Analysis}

The production of $\mathrm{Fe}(\mathrm{II})_{\mathrm{aq}}$ in the experiments was assumed to be a pseudo-first-order process as follows:

$$
\mathrm{Fe}(\mathrm{III})_{\mathrm{PA}} \stackrel{k^{\prime}}{\rightarrow} \mathrm{Fe}(\mathrm{II})_{\mathrm{aq}}
$$

where $\mathrm{Fe}(\mathrm{III})_{\mathrm{PA}} \equiv$ photochemically available $\mathrm{Fe}(\mathrm{III})$ and $\mathrm{k}^{\prime} \equiv$ pseudo-first-order rate constant; the corresponding rate law is given by

$$
\frac{d\left[\mathrm{Fe}(\mathrm{III})_{\mathrm{PA}}\right]}{d t}=-k^{\prime}\left[\mathrm{Fe}(\mathrm{III})_{\mathrm{PA}}\right]
$$

integration yields

$$
\left[\mathrm{Fe}(\mathrm{III})_{\mathrm{PA}}\right]=\left[\mathrm{Fe}(\mathrm{III})_{\mathrm{PA}}\right]_{0} e^{-k^{\prime} t} \text {. }
$$

The mass (mole) balance on $\left[\mathrm{Fe}(\mathrm{II})_{\mathrm{dq}}\right]$ is given by

$$
\left[\mathrm{Fe}(\mathrm{II})_{\mathrm{dq}}\right]=\left[\mathrm{Fe}(\mathrm{II})_{\mathrm{dq}}\right]_{0}+\left(\left[\mathrm{Fe}(\mathrm{III})_{\mathrm{PA}}\right]_{\mathrm{0}}-\left[\mathrm{Fe}(\mathrm{III})_{\mathrm{PA}}\right]\right)
$$

Combining (3) and (4) yields (5):

$$
\left[\mathrm{Fe}(\mathrm{II})_{\mathrm{aq}}\right]=\left[\mathrm{Fe}(\mathrm{II})_{\mathrm{aq}}\right]_{0}+\left[\mathrm{Fe}(\mathrm{III})_{\mathrm{PA}}\right]_{0}\left(1-e^{-k^{\prime} t}\right) .
$$

Values for $\left[\mathrm{Fe}(\mathrm{II})_{\mathrm{aq}}\right]_{0},\left[\mathrm{Fe}(\mathrm{III})_{\mathrm{PA}}\right]_{0}$ and $k^{\prime}$ were determined by fitting the experimental data to (5). Total photochemically available $\mathrm{Fe}\left(\mathrm{Fe}_{\mathrm{PA}, \text { total }}\right)$ was then defined as

$$
\left[\mathrm{Fe}_{\mathrm{PA}, \text { total }}\right]=\left[\mathrm{Fe}(\mathrm{II})_{\mathrm{aq}}\right]_{0}+\left[\mathrm{Fe}(\mathrm{III})_{\mathrm{PA}}\right]_{\mathrm{O}} \text {. }
$$

These fitted parameters (along with the volume of solution in the experiment and the volume of air sampled) were then used to calculate the atmospheric concentrations of $\mathrm{Fe}(\mathrm{II})_{\text {soluble }}$ (using $\left[\mathrm{Fe}(\mathrm{II})_{\mathrm{aq}}\right]_{0}$ ) and $\mathrm{Fe}_{\mathrm{PA}, \text { total }}$ (using $\left[\mathrm{Fe}_{\mathrm{PA}, \text { total }}\right)$ ).

\section{Computational Determination of Chemical Speciation}

Chemical speciation calculations were performed using the program MINEQL [Westall et al., 1976] which uses the equilibrium constant approach (defined by a system of mass action equations) to solve a chemical equilibrium problem.

\section{Results and Discussion}

A typical kinetic profile for $\mathrm{Fe}(\mathrm{II})_{\mathrm{aq}}$ released photochemically from an aerosol sample is shown in Figure 3. At $t=0 \mathrm{~min}$ the shutter is opened, allowing the solution and sample filter to be irradiated. [ $\left.\mathrm{Fe}(\mathrm{II})_{\mathrm{aq}}\right]$ increased until a steady state was reached (in some experiments there was no measured increase in [ $\left.\mathrm{Fe}(\mathrm{II})_{\mathrm{aq}}\right]$, in which case the pseudo-first-order rate constant was not measurable). The total $\mathrm{Fe}$ in the solution and on the filter was analyzed at the end of the experiment. The observed 


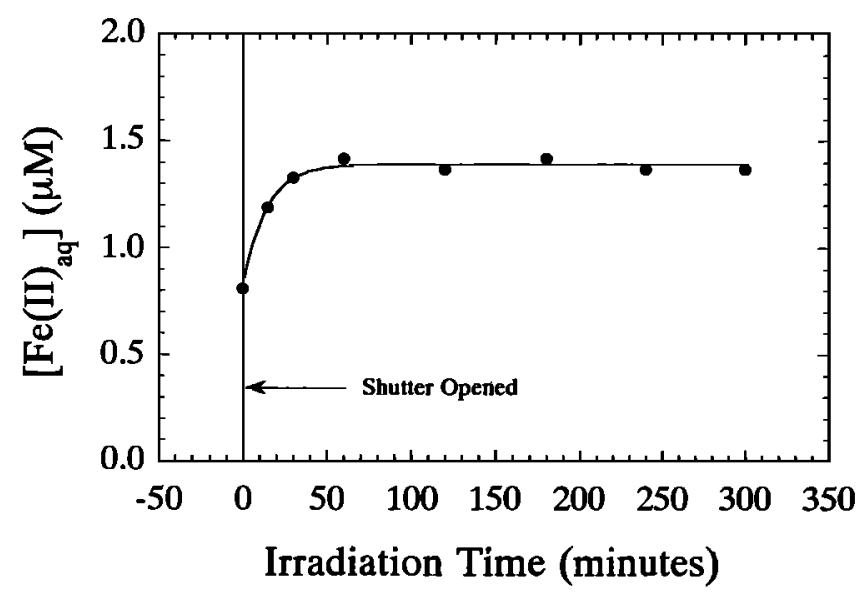

Figure 3. $\mathrm{Fe}(\mathrm{II})_{\mathrm{aq}}$ production curve in a typical photochemically available Fe experiment. The ambient aerosol sample used for this experiment was collected at Yosemite National Park, California, from July 29 to August 9, 1993.

[Fe(II) $\left.)_{\mathrm{aq}}\right]$ versus time curve was fitted according to (5) to yield $[\mathrm{Fe}(\mathrm{II})]_{0},\left[\mathrm{Fe}(\mathrm{III})_{\mathrm{PA}}\right]_{0}$, and $k^{\prime}$. These concentrations were then used to determine the atmospheric concentrations of soluble $\mathrm{Fe}(\mathrm{II})\left(\mathrm{Fe}(\mathrm{II})_{\text {soluble }}\right)$ and total photochemically available $\mathrm{Fe}$ $\left(\mathrm{Fe}_{\text {PA,total }}\right)$.

Experiments were not conducted to determine Fe(II) production in the dark, since previous studies showed no (or extremely slow) $\mathrm{Fe}$ (II) production in the absence of light compared to irradiated solutions [Zhu et al., 1993; Siefert et al., 1994]. Zhu et al. [1993] found that Fe(II) concentrations, in extracted aerosol filter sample solutions, increased rapidly when the solutions were exposed to sunlight.

The total dissolved solid (TDS) concentrations due to the dissolution and suspension of the aerosol sample on the filter (excluding the TDS associated with the formate buffer solution) were between 3.1 and $48.3 \mathrm{mg} \mathrm{L}^{-1}$ for all the experiments. Using data from Erel et al. [1993], TDS concentrations for fogwater and cloudwater samples were calculated by summing the concentrations cations, anions, metals, and total organic anions for the different samples. The TDS for these fogwater and cloudwater samples ranged from 21 to $355 \mathrm{mg}$ $\mathrm{L}^{-1}$. The TDS concentrations in the experiments were in the lower range of these observed TDS concentrations for fogwater and cloudwater.

\section{Effect of Formate Concentration and Light Intensity}

Experiments were performed on ambient aerosol samples collected in Pasadena where the formate concentration $\left(\left[\mathrm{HCO}_{2}^{-}\right]_{\mathrm{T}}\right)$ was varied to determine its effect on the $\mathrm{Fe}(\mathrm{II})_{\mathrm{aq}}$ production rate (where $\left[\mathrm{HCO}_{2}^{-}\right]_{\mathrm{T}}=\left[\mathrm{HCO}_{2} \mathrm{H}\right]+\left[\mathrm{HCO}_{2}^{-}\right]$). Formate concentrations of $0,0.5$, and $6.0 \mathrm{mM}$ were used. The $p \mathrm{H}$ of the $0 \mathrm{mM}$ added formate system was adjusted using perchloric acid. Over this concentration range, only a small change in $\mathrm{Fe}(\mathrm{II})_{\mathrm{aq}}$ production rates or final [Fe(II) $)_{\mathrm{aq}}$ ] levels were observed (Figure 4). These results show that sufficient electron donors were present in the ambient aerosol for the

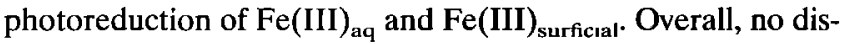
tinct correlation was observed between $d\left[\mathrm{Fe}(\mathrm{II})_{\mathrm{aq}}\right] / d t$ and $\left[\mathrm{HCO}_{2}^{-}\right]_{\mathrm{T}}$, or between final $\left[\mathrm{Fe}(\mathrm{II})_{\mathrm{aq}}\right]$ and $\left[\mathrm{HCO}_{2}^{-}\right]_{T}$.

Several experiments were also performed to determine if the reduction rate constant(s) were significantly greater than the oxidation rate constant(s) after $\left[\mathrm{Fe}(\mathrm{II})_{\mathrm{aq}}\right]$ had reached a steady state at the end of the experiments. The absolute rates of $\mathrm{Fe}(\mathrm{II})_{\mathrm{aq}}$ oxidation and $\mathrm{Fe}(\mathrm{III})_{\mathrm{aq}}$ reduction are equal at the steady state, but the concentrations of $\mathrm{Fe}(\mathrm{II})_{\mathrm{aq}}$ and $\mathrm{Fe}(\mathrm{III})_{\mathrm{aq}}$ change to meet this steady state conidition depending on the redox kinetics, as the following equations illustrate:

$$
\begin{aligned}
& \mathrm{Fe}(\mathrm{III})_{\mathrm{aq}} \stackrel{k_{\text {reduction }}}{\longrightarrow} \mathrm{Fe}(\mathrm{II})_{\mathrm{aq}}, \\
& \mathrm{Fe}(\mathrm{II})_{\mathrm{aq}} \stackrel{k_{\text {oxidation }}}{\longrightarrow} \mathrm{Fe}(\mathrm{III})_{\mathrm{aq}} .
\end{aligned}
$$

It should be noted that $\dot{k}_{\text {reduction }}$ in this analysis is not necessarily the same as the pseudo-first-order rate constant $\left(k^{\prime}\right)$ in (1). For example, the initial Fe could be a solid Fe oxyhydroxide which follows dissolution kinetics ( $k^{\prime}$ in (1)); and after the $\mathrm{Fe}$ is in solution, it would follow the faster homogeneous kinetics of (7) and (8). The overall process is described kinetically as follows:

$\frac{d\left[\mathrm{Fe}(\mathrm{II})_{\mathrm{aq}}\right]}{d t}=k_{\text {oxidation }}\left[\mathrm{Fe}(\mathrm{II})_{\mathrm{aq}}\right]-k_{\text {reduction }}\left[\mathrm{Fe}(\mathrm{III})_{\mathrm{aq}}\right]$

where

$$
\left[\mathrm{Fe}_{\mathrm{PA}, \text { lotal }} \mathrm{j}=\left[\mathrm{Fe}(\mathrm{II})_{\mathrm{aq}}\right]+\left[\mathrm{Fe}(\mathrm{III})_{\mathrm{aq}}\right] .\right.
$$

At steady state,

$$
\frac{d\left[\mathrm{Fe}(\mathrm{II})_{\mathrm{aq}}\right]}{d t}=0
$$

therefore combining (9), (10), and (11) and rearranging gives

$$
\frac{\left[\mathrm{Fe}(\mathrm{II})_{\mathrm{aq}}\right]}{\left[\mathrm{Fe}_{\mathrm{PA}, \text { ocal }}\right]}=\frac{1}{\frac{k_{\text {oxidation }}}{k_{\text {reduction }}}+1}
$$

In order for (5) to be valid, the ratio $k_{\text {oxidation }} / k_{\text {reduction }}$ must be $\ll 1$. This condition was tested after [Fe(II) $\left.)_{\mathrm{aq}}\right]$ reached a steady state by increasing $I_{0}$ by a factor of 3 or 10 . This increase in incident light intensity was assumed to increase $k_{\text {reduction; }}$; however, $k_{\text {oxidation }}$ might also be expected to increase since many oxidants have photochemical origins. In either case, $k_{\text {reduction }}$ and $k_{\text {oxidation }}$ are unlikely to change in such a way that $k_{\text {oxidation }} / k_{\text {reduction }}$ remains exactly the same after increasing the light intensity. Therefore by changing the light intensity and by

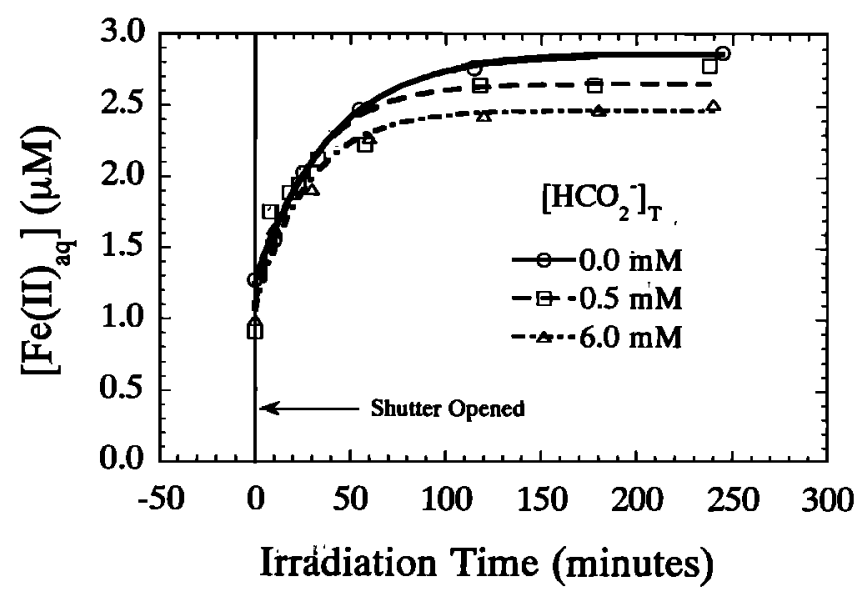

Figure 4. Effect of varying formic concentration on $\mathrm{Fe}(\mathrm{II})_{\mathrm{aq}}$ production rate. 
Table 1. Summary of Ambient Aerosol Collection Locations, Collection Times, Total Suspended Particulate, and Meteorological Conditions

\begin{tabular}{|c|c|c|c|c|}
\hline Label & Location $^{\mathbf{a}}$ & Collection Time & $\mathrm{TSP}^{\mathrm{b}} \mu \mathrm{g} \mathrm{m}^{-3}$ & Meteorologic Conditions ${ }^{c}$ \\
\hline WMNY 1 & WMNY & Sept. 22, 19921100 to Oct. 6, 19921215 & $11.2 \pm 6.0$ & high precipitation \\
\hline WMNY 2 & WMNY & Oct. 6, 19921310 to Oct. 20, 19921305 & $6.2 \pm 0.3$ & high precipitation \\
\hline WMNY 3 & WMNY & Oct. 20,19921305 to Nov. 3, 19921252 & $5.4 \pm 0.3$ & high precipitation \\
\hline WMNY 4 & WMNY & Nov. 3, 19921300 to Nov. 18,19921130 & $4.1 \pm 0.2$ & high precipitation \\
\hline WMNY 5 & WMNY & Nov. 18,19921133 to Dec. 1,19921006 & $3.9 \pm 0.2$ & high precipitation \\
\hline WMNY 6 & WMNY & May 12,19930842 to May 26, 19931005 & $11.1 \pm 0.6$ & hıgh precipitation \\
\hline PCA 1 & PCA & Feb. 21,19931600 to March 1, 19931600 & $24.7 \pm 0.2$ & E source, rain \\
\hline PCA 2 & PCA & Aug. 27, 19931430 to Sept. 4, 19931430 & $41.2 \pm 2.1$ & W source (marine/anthropogenic) \\
\hline PCA 3 & PCA & Oct. 27,19931000 to Oct. 29,19931200 & $182 \pm 9.9$ & Santa Ana winds, Altadena fires \\
\hline YNPCA 1 & YNPCA & Nov. 9, 19931530 to Nov. 17,19931400 & $4.6 \pm 0.2$ & W to NW source (marine/S.F.) \\
\hline YNPCA 2 & YNPCA & Nov. 30,19921300 to Dec. 13,19921200 & $4.3 \pm 0.2$ & precipitation \\
\hline YNPCA 3 & YNPCA & July 22, 19931330 to July 29, 19931330 & $17.2 \pm 0.1$ & E source (continental), dry \\
\hline YNPCA 4 & YNPCA & July 29,19931330 to August 9,19930900 & $20.1 \pm 1.0$ & E source (continental), dry \\
\hline YNPCA 5 & YNPCA & Qct. 5,19931200 to Oct. 17,19930730 & $9.4 \pm 0.2$ & W source (marine) \\
\hline SNICA 1 & SNICA & Nov. 2,19931200 to Nov. 7, 19930030 & $52.1 \pm 2.6$ & Santa Ana winds, Malibu fires \\
\hline SNICA 2 & SNICA & Nov. 17,19931130 to Dec. 1,19930840 & $17.9 \pm 2.8$ & W source (marine) \\
\hline
\end{tabular}

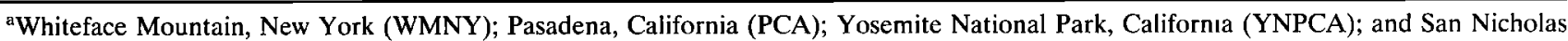
Island, California (SNICA).

'Total suspended particulate (TSP).

${ }^{c}$ Using NOAA Daily Weather Maps, Climate Analysis Center.

measuring $\left[\mathrm{Fe}(\mathrm{II})_{\mathrm{aq}}\right]$, the condition of $k_{\text {oxıdation }} / k_{\text {reduction }} \ll 1$ was verified. In each case, $\left[\mathrm{Fe}(\mathrm{II})_{\mathrm{aq}}\right]$ did not change after an increase in $I_{0}$. These results showed that increasing the incident light intensity by a factor of 3 or 10 after the steady state condition was reached did not influence the final steady state amount of $\mathrm{Fe}(\mathrm{II})_{\text {aq }}$ produced in the experiment. Thus we assumed that the other experiments also conformed to the condition $k_{\text {oxidation }} / k_{\text {reductoon }} \ll 1$. Therefore the steady-state $\left[\mathrm{Fe}(\mathrm{II})_{\mathrm{aq}}\right]$ at the end of these experiments was used to calculate the total photochemically available $\mathrm{Fe}\left(\mathrm{Fe}_{\mathrm{PA}, \text { total }}\right)$ in the experiments.

\section{Atmospheric Concentrations of $\mathrm{Fe}(\mathrm{II})_{\text {soluble }}, \mathrm{Fe}_{\mathrm{PA}, \text { total }}$ and Fe $_{\text {total }}$}

Table 1 provides a summary of locations, collection times, total suspended particulate (TSP) concentrations and meteorological conditions for the ambient aerosol samples. A summary of results of the photochemical experiments is given in Table 2. These results include the atmospheric concentrations of $\mathrm{Fe}_{\text {total }}, \mathrm{Fe}(\mathrm{II})_{\text {soluble, }}$ and $\mathrm{Fe}_{\mathrm{PA} \text {,total }}$. The pseudo-first-order rate constant for the photoreduction of $\mathrm{Fe}(\mathrm{III})_{\mathrm{PA}}$ to $\mathrm{Fe}(\mathrm{II})_{\mathrm{aq}}$ and the initial production rate of $\mathrm{Fe}$ (II) $)_{\mathrm{aq}}$ are also tabulated. All of the experiments were performed at $p \mathrm{H}$ of $4.25 \pm 0.05$.

The urban sampling site in Pasadena (California) is located near Los Angeles (LA). This site had the largest concentrations of $\mathrm{Fe}_{\text {total }}$ and $\mathrm{Fe}_{\mathrm{PA} \text {,total }}$, with average concentrations of 660 and $120 \mathrm{ng} \mathrm{m}^{-3}$, respectively. Assuming a cloud liquid water content ( $\mathrm{LWC}$ ) of $10^{-6}\left(1.0 \mathrm{~cm}^{3} \mathrm{H}_{2} \mathrm{O}\right.$ per $\mathrm{m}^{3}$ of air) and incorporation of all of the ambient aerosol particulate matter into the cloudwater, the average aqueous concentrations of $\mathrm{Fe}_{\text {total }}$ and $\mathrm{Fe}_{\mathrm{PA} \text {,otal }}$ would have been 12 and $2 \mu \mathrm{M}$, respectively. Under conditions in which easterly winds prevailed with high levels of precipitation, the $\mathrm{Fe}_{\mathrm{PA} \text {,total }}$ concentrations were reduced by over $50 \%$, and $\mathrm{Fe}_{\text {total }}$ was also reduced by about $40 \%$. The elevated Fe concentrations in Pasadena, which is influenced by onshore breezes, are probably due to the anthropogenic loading as air parcels are advected across the LA basin.

Aerosol samples, collected in Pasadena during the Altadena hillside fires of late October and early November 1993 (a city bordering the northern edge of Pasadena), contained large amounts of ash and had a TSP concentration of $182 \pm 10 \mu \mathrm{g}$ $\mathrm{m}^{-3}$. Fe concentrations in these fire-related samples were 7 times greater for $\mathrm{Fe}_{\text {total }}$ but only 1.5 times greater for $\mathrm{Fe}_{\mathrm{PA} \text {,tolal }}$ then other aerosol samples collected from the same site when there were no fires. From the data in Table 2 it is clear that the differences for $\mathrm{Fe}_{\text {total }}, \mathrm{Fe}$ (II) coluble, $_{\text {, }}$ and $\mathrm{Fe}_{\mathrm{PA} \text {,total }}$ between repeated experiments are unusually high for ambient aerosol collected during the Altadena fires. This variability in samples collected during the same event may be the result of the variable composition of ash collected among filters. The high $\mathrm{Fe}$ and TSP concentrations in this case are the direct result of the fires, probably due to the combustion of biomass and the suspension of dust and soil particles. The pseudo-first-order rate constant calculated for these experiments was significantly smaller than the $k$ values calculated for the other aerosol samples (except for the SNICA 2 sample which was also collected downwind of a fire). The average half-life of $\mathrm{Fe}(\mathrm{III})_{\mathrm{PA}}$ for the PCA 3 sample is approximately $360 \mathrm{~min}$. For comparison the average half-life of $\mathrm{Fe}(\mathrm{III})_{\mathrm{PA}}$ is approximately $17 \mathrm{~min}$ for all the other calculated rate constants in Table 2 (not including the SNICA 2 sample). The Altadena fire resulted in increases in $\mathrm{Fe}_{\text {total }}$ atmospheric concentrations but did not increase $\mathrm{Fe}_{\mathrm{PA} \text {,total }}$ concentrations significantly. However, the $\mathrm{Fe}_{\mathrm{PA} \text {,total }}$ that was produced during the fire storm was the least reactive (based on $k^{\prime}$ ) compared to the other samples.

Aerosol samples from San Nicholas Island, California (100 km offshore from LA), contained substantially less $\mathrm{Fe}_{\text {total }}$ and $\mathrm{Fe}_{\text {PA,total }}$ than the Pasadena samples. The aerosol collected on San Nicholas Island is primarily of marine origin, although some anthropogenic input can occur due to offshore airflow from the LA basin. Aerosol sources from the LA basin have been detected, when an air parcel oscillates between San Nicholas Island and LA, due to the alternating onshore and offshore breezes [Rosenthal et al., 1979]. In addition, anthropogenic input to San Nicholas Island from the Point Conception and Morro Bay areas has been documented [Rosenthal et al., 1979]. Aerosol samples were also collected on San Nicholas Island during the 1993 Malibu, California, fire. Strong Santa 
Table 2. Atmospheric Concentrations of Total $\mathrm{Fe}\left(\mathrm{Fe}_{\text {total }}\right)$, Soluble Ferrous $\mathrm{Fe}$ (Fe(II) $\left.)_{\text {soluble }}\right)$, and Total Photochemically Available $\mathrm{Fe}\left(\mathrm{Fe}_{\mathrm{PA}, \text { total }}\right)$

\begin{tabular}{|c|c|c|c|c|c|c|c|}
\hline Label & $\begin{array}{l}\mathrm{Fe}_{\text {total }} \\
\mathrm{ng} \mathrm{m}^{-3}\end{array}$ & $\begin{array}{l}\mathrm{Fe}(\mathrm{II})_{\text {soluble }} \\
\mathrm{ng} \mathrm{m}^{-3}\end{array}$ & $\begin{array}{l}\mathrm{Fe}_{\mathrm{PA}, \text { total }} \\
\mathrm{ng} \mathrm{m}^{-3}\end{array}$ & $\underset{\%}{\mathrm{Fe}(\mathrm{II})_{\text {soluble }}} / \mathrm{Fe}_{\text {total }}$ & $\underset{\%}{\mathrm{Fe}_{\mathrm{PA}, \text { total }} / \mathrm{Fe}_{\text {total }}}$ & $\begin{array}{c}k \\
\min ^{-1}\end{array}$ & $\underset{\mathrm{nM} \mathrm{s}^{-1}}{d[\mathrm{Fe}(\mathrm{II})] / d t}$ \\
\hline WMNY 1 & $32 \pm 3$ & $23 \pm 4$ & $32 \pm 6$ & $70.2 \pm 15.4$ & $99.5 \pm 20.9$ & $\mathbf{N M}^{\mathbf{a}}$ & NM \\
\hline WMNY 1 & $29 \pm 2$ & $15 \pm 1$ & $21 \pm 2$ & $53.3 \pm 6.3$ & $71.5 \pm 8.4$ & $0.0596 \pm 0.0341$ & $14.1 \pm 8.6$ \\
\hline WMNY 2 & $24 \pm 2$ & $19 \pm 3$ & $26 \pm 4$ & $77.1 \pm 15.5$ & $108.6 \pm 20.4$ & $0.0262 \pm 0.0231$ & $90 \pm 8.5$ \\
\hline WMNY 3 & $18 \pm 2$ & $<4$ & $17 \pm 8$ & $<22$ & $94.4 \pm 47.2$ & NM & NM \\
\hline WMNY 4 & $12 \pm 1$ & $5 \pm 1$ & $11 \pm 1$ & $45.2 \pm 10.8$ & $87.3 \pm 14.5$ & $0.0094 \pm 0.0035$ & $2.3 \pm 0.9$ \\
\hline WMNY 5 & $10 \pm 1$ & $<5$ & $<7$ & $<50$ & $<70$ & NM & NM \\
\hline WMNY 6 & $72 \pm 6$ & $35 \pm 2$ & $40 \pm 3$ & $48.4 \pm 4.9$ & $55.9 \pm 6.0$ & $0.0409 \pm 0.0338$ & $10.0 \pm 9.0$ \\
\hline PCA 1 & $222 \pm 18$ & $42 \pm 3$ & $65 \pm 4$ & $18.7 \pm 2.0$ & $29.2 \pm 2.9$ & $0.0303 \pm 0.0070$ & $18.1 \pm 4.6$ \\
\hline PCA 1 & $197 \pm 16$ & $43 \pm 4$ & $73 \pm 5$ & $21.9 \pm 2.7$ & $37.2 \pm 4.0$ & $0.0091 \pm 0.0025$ & $7.1 \pm 2.1$ \\
\hline PCA 2 & $283 \pm 23$ & $32 \pm 14$ & $131 \pm 18$ & $11.2 \pm 5.1$ & $46.2 \pm 7.5$ & $0.0136 \pm 0.0042$ & $34.7 \pm 11.5$ \\
\hline PCA 2 & $304 \pm 24$ & $34 \pm 11$ & $121 \pm 15$ & $11.1 \pm 3.8$ & $39.9 \pm 5.7$ & $0.0115 \pm 0.0041$ & $25.9 \pm 9.7$ \\
\hline PCA 2 & $343 \pm 28$ & $43 \pm 8$ & $103 \pm 10$ & $12.5 \pm 2.5$ & $30.0 \pm 3.9$ & $0.0348 \pm 0.0088$ & $53.9 \pm 15.0$ \\
\hline PCA 2 & $305 \pm 27$ & $54 \pm 14$ & $130 \pm 17$ & $17.7 \pm 4.8$ & $42.7 \pm 6.9$ & $0.0114 \pm 0.0044$ & $22.3 \pm 9.1$ \\
\hline $\mathrm{PCA} 2$ & $217 \pm 18$ & $41 \pm 4$ & $96 \pm 6$ & $19.0 \pm 2.6$ & $44.0 \pm 4.6$ & $0.0357 \pm 0.0065$ & $50.1 \pm 9.8$ \\
\hline PCA 3 & $3367 \pm 297$ & $41 \pm 9$ & $308 \pm 11$ & $1.2 \pm 0.3$ & $9.2 \pm 0.9$ & $0.0022 \pm 0.0002$ & $4.0 \pm 0.4$ \\
\hline PCA 3 & $1764 \pm 132$ & $65 \pm 14$ & $219 \pm 17$ & $3.7 \pm 0.8$ & $12.4 \pm 1.3$ & $0.0017 \pm 0.0003$ & $1.8 \pm 0.4$ \\
\hline PCA 3 & $2105 \pm 160$ & $55 \pm 7$ & $59 \pm 10$ & $2.6 \pm 0.4$ & $2.8 \pm 0.5$ & NM & NM \\
\hline PCA 3 & $3180 \pm 280$ & $49 \pm 18$ & $107 \pm 23$ & $1.6 \pm 0.6$ & $3.4 \pm 0.8$ & $0.0019 \pm 0.0015$ & $0.7 \pm 0.6$ \\
\hline YNPCA 1 & $23 \pm 2$ & $16 \pm 4$ & $18 \pm 4$ & $67.8 \pm 16.3$ & $76.6 \pm 19.3$ & NM & NM \\
\hline YNPCA 2 & $31 \pm 2$ & $20 \pm 2$ & $26 \pm 2$ & $64.9 \pm 7.6$ & $83.3 \pm 10.0$ & $0.0400 \pm 0.0276$ & $9.6 \pm 7.2$ \\
\hline YNPCA 2 & $31 \pm 2$ & $20 \pm 2$ & $26 \pm 2$ & $64.9 \pm 7.6$ & $83.3 \pm 10.0$ & $0.0400 \pm 0.0278$ & $9.6 \pm 7.2$ \\
\hline YNPCA 3 & $84 \pm 7$ & $<9$ & $25 \pm 5$ & $<11$ & $30.2 \pm 6.2$ & $0.0375 \pm 0.0181$ & $13.9 \pm 7.2$ \\
\hline YNPCA 3 & $93 \pm 8$ & $11 \pm 2$ & $32 \pm 3$ & $11.4 \pm 2.7$ & $34.9 \pm 4.5$ & $0.0190 \pm 0.0046$ & $9.4 \pm 2.4$ \\
\hline YNPCA 4 & $158 \pm 11$ & $3 \pm 1$ & $49 \pm 2$ & $21.2 \pm 1.7$ & $31.0 \pm 2.4$ & $0.0582 \pm 0.0079$ & $25.5 \pm 3.8$ \\
\hline YNPCA 5 & $53 \pm 1$ & $<\overline{5}$ & $11 \pm 3$ & $<9$ & $20.5 \pm 4.8$ & $0.0205 \pm 0.0082$ & $7.9 \pm 3.4$ \\
\hline YNPCA 5 & $59 \pm 2$ & $<5$ & $11 \pm 1$ & $<9$ & $17.9 \pm 1.9$ & $0.1673 \pm 0.1043$ & $60.8 \pm 38.1$ \\
\hline YNPCA 5 & $74 \pm 3$ & $<5$ & $10 \pm 1$ & $<7$ & $13.9 \pm 0.6$ & $0.1459 \pm 0.0115$ & $51.4 \pm 4.2$ \\
\hline YNPCA 5 & $109 \pm 1$ & $<5$ & $11 \pm 1$ & $<5$ & $10.3 \pm 0.4$ & $0.0087 \pm 0.0081$ & $27.1 \pm 2.6$ \\
\hline SNICA 1 & $316 \pm 23$ & $70 \pm 8$ & $85 \pm 11$ & $22.1 \pm 3.1$ & $27.0 \pm 3.9$ & NM & NM \\
\hline SNICA 2 & $159 \pm 5$ & $<7$ & $10 \pm 2$ & $<70$ & $6.6 \pm 1.4$ & $0.0081 \pm 0.0046$ & $2.8 \pm 1.7$ \\
\hline SNICA 2 & $195 \pm 6$ & $<7$ & $16 \pm 7$ & $<44$ & $8.1 \pm 3.8$ & $0.0051 \pm 0.0041$ & $3.1 \pm 2.6$ \\
\hline SNICA 2 & $117 \pm 9$ & $20 \pm 2$ & $26 \pm 2$ & $17.5 \pm 2.0$ & $22.4 \pm 2.5$ & $0.0014 \pm 0.0006$ & $0.4 \pm 0.2$ \\
\hline
\end{tabular}

Also, the pseudo-first-order rate constant $\left(k^{\prime}\right)$ for the photoreduction of $\mathrm{Fe}(\mathrm{III})_{\mathrm{PA}}$ to $\mathrm{Fe}(\mathrm{II})_{\mathrm{dy}}$ and the initial production rate of $\mathrm{Fe}(\mathrm{II})_{\mathrm{ay}}$. ${ }^{\mathrm{A}}$ Not measureable.

Ana wind conditions spread the smoke plume from these fires directly over the island (Figure 5). However, since the site is over $100 \mathrm{~km}$ from the source of the plume, large pieces of ash were absent. The aerosol samples collected over this period showed a fourfold increase in $\mathrm{Fe}_{\mathrm{PA} \text {,toral }}$ and threefold increase in $\mathrm{Fe}_{\text {total }}$ compared to the San Nicholas Island, California, sample (SNICA 2) which was of marine origin. This increase

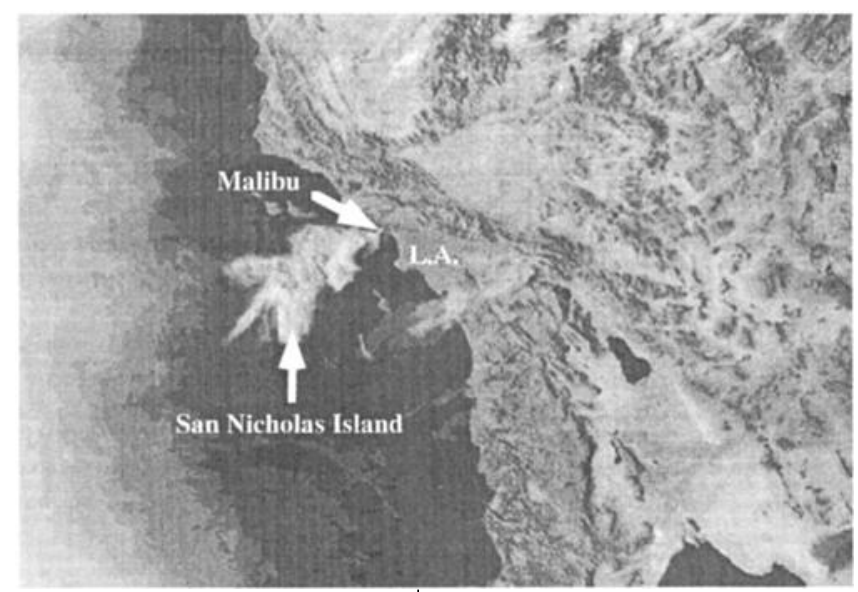

Figure 5. Satellite image of the smoke plume from the 1993 Malibu, California, fires. was clearly due to airborne particulates created by the Malibu fire conditions.

The sampling site at Whiteface Mountain, New York, was subjected to the highest amount of precipitation. In the sampling period from September to December 1992, precipitation was measured on more than 60 days. The general airflow in this region, although highly variable, was dominated by wind from the northern Great Lakes region and southern Canada. At Whiteface Mountain the $\mathrm{Fe}_{\mathrm{PA} \text {,total }}$ and $\mathrm{Fe}_{\text {total }}$ concentrations appeared to decrease as the seasons changed from fall to winter. The ratio of $\mathrm{Fe}_{\mathrm{PA} \text {,tutal }}$ to $\mathrm{Fe}_{\text {total }}$ concentrations remained relatively constant throughout and was higher than at any other site. A high ratio of $\mathrm{Fe}_{\mathrm{PA}, \text { tutal }}$ to $\mathrm{Fe}_{\text {total }}$ concentrations (on average 85\%) suggests a "photochemical weathering" of Fe aerosol particles [Duce and Tindale, 1991; Zhuang et al., 1992a, b]. Since the air masses arriving at Whiteface Mountain had a high water content, $\mathrm{Fe}$ in the aerosol may have been more readily available because of the greater possibility of active cloudwater photochemistry than in aerosol samples collected from drier air masses. Before a cloud condensation nucleus (CCN) is deposited by precipitation, it often goes through a number of hydration and evaporation cycles. Junge [1964] estimated that a single CCN may undergo 10 hydration/ evaporation cycles before precipitation. The high frequency of precipitation at Whiteface Mountain as compared to Pasadena and the other West Coast sites may explain the higher observed ratios of $\mathrm{Fe}_{\mathrm{PA} \text {,total }}$ to $\mathrm{Fe}_{\text {total }}$ concentrations. 
Ambient aerosol collected at Yosemite National Park, California, also showed a seasonal trend in the ratios of $\mathrm{Fe}_{\mathrm{PA}, \text { total }}$ to $\mathrm{Fe}_{\text {total }}$ concentrations. A pronounced decrease in the ratio of $\mathrm{Fe}_{\mathrm{PA} \text {,total }}$ to $\mathrm{Fe}_{\text {total }}$ concentrations occurs during the months of November and December compared to July. The air parcels during the winter originated primarily from the coastal region, while during the summer, air parcels originated from continental areas. This directional difference in the air masses may explain the change in the ratios of $\mathrm{Fe}_{\mathrm{PA}, \text { total }}$ to $\mathrm{Fe}_{\text {total }}$ concentrations in the associated aerosol. Furthermore, the moist marine air may have induced more chemical weathering of the aerosol particles leading to higher ratios of $\mathrm{Fe}_{\mathrm{PA}, \text { total }}$ to $\mathrm{Fe}_{\text {total }}$ concentrations.

\section{Comparison of Experimental Fe(II) Photoproduction Rates to Known Fe Oxidation/Reduction Rates}

Iron oxidation and reduction rates in the photochemically available iron experiments were calculated and compared to the observed photoproduction of $\mathrm{Fe}(\mathrm{II})_{\mathrm{aq}}$. The Fe oxidation and reduction rates were calculated using rate constants available in the literature. The following reactions were used in the calculation:

$$
\begin{gathered}
\mathrm{Fe}^{2+}+\mathrm{H}_{2} \mathrm{O}_{2} \rightarrow \mathrm{Fe}^{3+}+\cdot \mathrm{OH}+\mathrm{OH}^{-}, \\
\mathrm{Fe}(\mathrm{OH})^{+}+\mathrm{H}_{2} \mathrm{O}_{2} \rightarrow \mathrm{Fe}(\mathrm{OH})^{2+}+\cdot \mathrm{OH}+\mathrm{OH}^{-}, \\
\mathrm{Fe}(\mathrm{OH})^{2+}+h \nu \rightarrow \mathrm{Fe}^{2+}+\cdot \mathrm{OH}, \\
\mathrm{Fe}(\mathrm{OOCCOOH})^{2+}+h \nu \rightarrow \mathrm{Fe}^{2+}+2 \mathrm{CO}_{2}+\cdot \mathrm{HO}_{2} .
\end{gathered}
$$

The oxidation of $\mathrm{Fe}(\mathrm{II})$ by $\mathrm{O}_{2}$ is extremely slow under these conditions [Wehrli, 1990] and therefore was not included. Other reactions are also possible (including heterogeneous reactions); however, the above reactions were chosen since they are representative of the likely range of reactions possible. Table 3 shows the concentrations used in the reaction rate calculations. A range of concentrations existed for each species in Table 3, and the concentrations in Table 3 are a representative set of values for the experiments shown in Table 2 . Table 4 shows the rate constants and calculated reaction rates. The

\begin{tabular}{|c|c|c|c|}
\hline $\begin{array}{l}\text { Components } \\
\text { and Species }\end{array}$ & $\log \beta_{t}^{d}$ & Reference $^{b}$ & Concentration $^{\mathrm{c}}$ \\
\hline$p \mathrm{H}$ & & & 4.25 \\
\hline Acetate $_{\text {total }}$ & & & $1.0 \times 10^{-5} \mathrm{M}$ \\
\hline Formate $_{\text {total }}$ & & & $5.0 \times 10^{-4} \mathrm{M}$ \\
\hline Oxalate $_{\text {total }}$ & & & $1.0 \times 10^{-6} \mathrm{M}$ \\
\hline $\mathrm{Fe}(\mathrm{II})_{\text {total }}$ & & & $1.0 \times 10^{-6} \mathrm{M}$ \\
\hline $\mathrm{Fe}(\text { III })_{\text {total }}$ & & & $1.0 \times 10^{-6} \mathrm{M}$ \\
\hline $\mathrm{Fe}^{2+}$ & & & $1.0 \times 10^{-6} \mathrm{M}$ \\
\hline $\mathrm{FeOH}^{+}$ & 4.5 & 1 & $4.5 \times 10^{-12} \mathrm{M}$ \\
\hline $\mathrm{Fe}^{3+}$ & & & $8.2 \times 10^{-9} \mathrm{M}$ \\
\hline $\mathrm{FeOH}^{2+}$ & 11.4 & 2 & $3.9 \times 10^{-7} \mathrm{M}$ \\
\hline $\mathrm{Fe}(\mathrm{OH})_{2}^{+}$ & 20.1 & 2 & $3.3 \times 10^{-8} \mathrm{M}$ \\
\hline $\mathrm{Fe}(\text { oxalate })^{+}$ & 9.40 & 3 & $4.9 \times 10^{-7} \mathrm{M}$ \\
\hline $\mathrm{Fe}(\text { oxalate })_{2}^{-}$ & 16.2 & 3 & $7.4 \times 10^{-8} \mathrm{M}$ \\
\hline $\mathrm{Fe}$ (oxalate) $)_{3}^{3-}$ & 20.8 & 3 & $7.0 \times 10^{-11} \mathrm{M}$ \\
\hline
\end{tabular}
results in Table 4 show that the $\mathrm{Fe}(\mathrm{III})_{\text {aq }}$ reduction rates are

Table 3. Thermodynamic Equilibrium Calculation for $\mathrm{Fe}(\mathrm{II})$ and $\mathrm{Fe}(\mathrm{III})$ Speciation

${ }^{\mathrm{a}} \boldsymbol{\beta}_{\boldsymbol{f}}$ is cumulative equilibrium constant.

b1, Smith and Martell [1974]; 2, Faust and Hoigné [1990]; 3, Lacroix [1949].

'Species concentrations were calculated using MINEQL [Westall, 1976].
Table 4. Rate Constants for $\mathrm{Fe}(\mathrm{II})_{\mathrm{aq}}$ Oxidation and $\mathrm{Fe}(\mathrm{III})_{\mathrm{aq}}$ Reduction Reactions and Calculated Fe Oxidation and Reduction Rates Using Information in Table 3 and Assuming $\left[\mathrm{H}_{2} \mathrm{O}_{2}\right]=1 \times 10^{-6} \mathrm{M}$

\begin{tabular}{llcc}
\hline Reaction & Rate Constant & Reference $^{\mathrm{a}}$ & $\begin{array}{c}d[\mathrm{Fe}(\mathrm{II})] / d t^{\mathrm{b}} \\
\mathrm{nM} \mathrm{s}\end{array}$ \\
\hline$(13)$ & $6.3 \times 10^{1} \mathrm{M}^{-1} \mathrm{~s}^{-1}$ & 1 & -0.06 \\
$(14)$ & $5.9 \times 10^{6} \mathrm{M}^{-1} \mathrm{~s}^{-1}$ & 2 & -0.03 \\
$(15)^{\mathrm{c}}$ & $6.3 \times 10^{-4} \mathrm{~s}^{-1}$ & 4 & 0.25 \\
$(16)^{\mathrm{c}}$ & $5.8 \times 10^{-2} \mathrm{~s}^{-1}$ & 5 & 4.3 \\
\hline
\end{tabular}

"1, Hartwick [1957]; 2, Millero and Sotolongo [1989]; 3, Wehrli [1990]; 4, Faust and Hoigné [1990]; 5, Zuo and Hoigné [1993].

"Minus sign indicates $-d[\mathrm{Fe}(\mathrm{II})] / d t$ and plus sign indicates $+d[\mathrm{Fe}(\mathrm{II})] / d t$.

${ }^{c}$ For clear sky photolysis (solar noon, June 30)

greater than $\mathrm{Fe}(\mathrm{II})_{\mathrm{aq}}$ oxidation rates. This calculation is in agreement with the experiments shown in Table 2, since $\mathrm{Fe}(\mathrm{II})_{\mathrm{aq}}$ was never observed to decrease in these experiments. The observed initial $\mathrm{Fe}(\mathrm{II})_{\mathrm{aq}}$ production rates in the experiments were between 0 and $60 \mathrm{nM} \mathrm{s}^{-1}$ (see Table 2), with an average value of $16 \mathrm{nM} \mathrm{s}^{-1}$. These observed rates are within or greater than calculated rates shown in Table 4. Overall, these observed rates are in reasonable agreement with the calculated rates, since the calculated rates use average concentrations for Fe, organic ligands, etc.

Using the observed initial $\mathrm{Fe}(\mathrm{II})_{\mathrm{aq}}$ production rates, we can also estimate the production of oxidants $\left(\mathrm{OH}^{-}\right.$, and $\left.\mathrm{HO}_{2}^{-}\right)$in the experiments due to $\mathrm{Fe}$ chemistry. Equations (15) and (16) show that the rate of $\mathrm{Fe}(\mathrm{II})_{\mathrm{aq}}$ production is equal to the oxidant production rate (actually the rate of $\mathrm{Fe}(\mathrm{II})_{\text {cly }}$ production is equal to the minimum oxidant production rate since cycling of $\mathrm{Fe}(\mathrm{II}) / \mathrm{Fe}$ (III) is possible). Therefore the estimated oxidant production rate is between 0 and $60 \mathrm{nM} \mathrm{s}^{-1}$, with an average value of $16 \mathrm{nM} \mathrm{s}^{-1}$. These values can be used as estimates of the oxidant production rate in the atmosphere by assuming a LWC of $\approx 10^{-6}$ and that the aerosol sampling duration was $\approx 7$ days. These assumptions would mean that $\approx 100 \mathrm{~mL}$ of water would be collected during this sampling duration if the LWC was always $10^{-6}$. And since the experiments use $80 \mathrm{~mL}$ of solution, it is reasonable to relate the estimated oxidant production in the experiments to aqueous phase atmospheric chemistry. Therefore the estimated cloudwater oxidant production rate in the atmosphere based on these experiments is between 0 and $60 \mathrm{nM} \mathrm{s}{ }^{-1}$, with an average value of $16 \mathrm{nM} \mathrm{s}^{-1}$. Chameides and Davis [1982] estimated the flux of oxidants to the aqueous phase from the gas phase in the atmosphere to be between 0.3 and $30 \mathrm{nM} \mathrm{s}^{-1}$. Therefore the estimated in situ oxidant production rate due to Fe chemistry is roughly equal to the estimated oxidant flux from the gas phase.

\section{Conclusions}

Photolysis of aqueous solutions containing ambient aerosol samples was performed in order to quantify the photochemically labile $\mathrm{Fe}$ available for aqueous photochemical reactions. The photochemically available Fe concentrations found ranged from $<4$ to $308 \mathrm{ng} \mathrm{m}^{-3}, \mathrm{Fe}_{\text {total }}$ concentrations ranged from 10 to $3400 \mathrm{ng} \mathrm{m}^{-3}$, and the percentage of photochemically available $\mathrm{Fe}$ to $\mathrm{Fe}_{\text {total }}$ ranged from 2.8 to $100 \%$ for aerosol samples collected in marine, coastal, and mountainous regions. The passage of air masses through climatic and anthropogenic re- 
gions has a demonstrable effect on the ratio of $\mathrm{Fe}_{\mathrm{PA}, \text { total }}$ to $\mathrm{Fe}_{\text {total }}$ concentrations. Wet conditions, in which the aerosol particles may undergo chemical weathering in clouds, appear to increase the relative amount of $\mathrm{Fe}_{\mathbf{P A} \text {,total }}$ compared to $\mathrm{Fe}_{\text {total }}$. The urban Los Angeles basin has higher atmospheric levels of $\mathrm{Fe}_{\text {total }}$, but the ratio of $\mathrm{Fe}_{\mathrm{PA} \text {,total }}$ to $\mathrm{Fe}_{\text {total }}$ concentrations remained relatively constant. $\mathrm{Fe}_{\mathrm{PA} \text {,total }}$ concentrations in the southern California region were not affected by extensive biomass burning during the fall of 1993 , even though $\mathrm{Fe}_{\text {total }}$ increased significantly. Overall, the $\mathrm{Fe}$ added to the atmosphere during these fires was not readily available for photochemical reactions. The observed $\mathrm{Fe}(\mathrm{II})_{\text {aq }}$ production rates in the experiments were in agreement with the calculated $\mathrm{Fe}(\mathrm{II})_{\mathrm{aq}}$ production rates using rate constants from the literature.

The estimated cloudwater oxidant production rate in the atmosphere based on these experiments is between 0 and 60 $\mathrm{nM} \mathrm{s}{ }^{-1}$, with an average value of $16 \mathrm{nM} \mathrm{s}^{-1}$. Chameides and Davis [1982] estimated the flux of oxidants to the aqueous phase from the gas phase in the atmosphere to be between 0.3 and $30 \mathrm{nM} \mathrm{s}{ }^{-1}$. Therefore the estimated in situ cloudwater oxidant production rate due to Fe chemistry is approximately equal to the estimated oxidant flux from the gas phase.

Acknowledgments. Special thanks are extended to Anne Foster and Richard MacDonald of the ASRC at Whiteface Mountain, Andy Friedland at Dartmouth College, Diane Ewell and Annie Esperanza of Sequoia National Park, and Jan van Wagtendonk at Yosemite National Park for their help. We also thank J. J. Morgan of Caltech for helpful discussions. Support for this research has been provided by a grant from the National Science Foundation, Division of Atmospheric Sciences, Atmospheric Chemistry Section (ATM 9015775; ATM 9303024). This research was also sponsored by the U.S. Department of Energy, Office of Energy Research, Environmental Sciences Division, Office of Health and Environmental Research, under appointment to the Graduate Fellowships for Global Change administered by Oak Ridge Institute for Science and Education.

\section{References}

Behra, P., and L. Sigg, Evidence for redox cycling of iron in atmospheric water droplets, Nature, 344, 419-421, 1990.

Breytenbach, L., W. Vanpareen, J. J. Pienaar, and R. van Eldik, The influence of organic acids and metal ions on the kinetics of the oxidation of sulfur(IV) by hydrogen peroxide, Atmos. Environ., 28, 2451-2459, 1994.

Carter, P., Spectrophotometric determination of serum iron at the submicrogram level with a new reagent (ferrozine), Anal. Biochem., 40, 450-458, 1971.

Cass, G. R., and G. J. McRae, Source-receptor reconciliation of routine air monitoring data for trace metals: An emission inventory assisted approach, Environ. Sci. Technol., 17, 129-139, 1983.

Chameides, W. L., and D. D. Davis, The free radical chemistry of cloud droplets and its impact upon the composition of rain, J. Geophys. Res., 87, 4863-4877, 1982.

Demerjian, K. L., K. L. Schere, and J. T. Peterson, Theoretical estimates of actinic (spherically integrated) flux and photolytic rate constants of atmospheric species in the lower troposphere, $A d v$. Environ. Sci. Technol., 10, 369, 1980.

Ditullio, G. R., D. A. Hutchins, and K. W. Bruland, Interaction of iron and major nutrients controls phytoplankton growth and species composition in the tropical North Pacific Ocean, Limnol. Oceanogr., $38,495-508,1993$.

Duce, R. A., and N. W. Tindale, Atmospheric transport of iron and its deposition in the ocean, Limnol. Oceanogr., 36, 1715-1726, 1991.

Erel, Y., S. O. Pehkonen, and M. R. Hoffmann, Redox chemistry of iron in fog and stratus clouds, J. Geophys. Res., 98, 18,423-18,434, 1993.

Faust, B. C., and J. M. Allen, Aqueous phase photochemical sources of peroxyl radicals and singlet molecular oxygen in clouds and fogs, $\boldsymbol{J}$. Geophys. Res., 97, 12,913-12,926, 1992.
Faust, B. C., and J. Hoigné, Photolysis of Fe(III)-hydroxy complexes as sources of $\mathrm{OH}$ radicals in clouds, fog and rain, Atmos. Environ., 24A, $79-89,1990$.

Faust, B. C., and R. G. Zepp, Photochemistry of aqueous iron(III)polycarboxylate complexes: Roles in the chemistry of atmospheric and surface waters, Environ. Sci. Technol., 27, 2517-2522, 1993.

Faust, B. C., C. Anastasio, J. M. Allen, and T. Arakaki, Aqueous phase photochemical formation of peroxides in authentic cloud and fogwaters, Science, 260, 73-75, 1993.

Fuzzi, S., G. Orsi, G. Nardini, M. C. Facchini, E. McLaren, and M. Mariotti, Heterogeneous processes in the Po Valley radiation fog, J. Geophys. Res., 93, 11,141-11,151, 1988.

Gomes, L., and D. A. Gillette, A comparison of characteristics of aerosol from dust storms in central Asia with soil derived dust from other regions, Atmos. Environ., 27, 2539-2544, 1993.

Gunz, D. W., and M. R. Hoffmann, Atmospheric chemistry of peroxides: A review, Atmos. Environ., A24, 1601-1633, 1990.

Hartwick, T. J., The rate constant of the reaction between ferrous ions and hydrogen peroxide in acid solution, Can. J. Chem., 35, 428-436, 1957.

Heller, H. G., and J. R. Langan, A new reusable chemical actinometer, J. Chem. Soc. Perkin Trans. I, 341, 1981.

Hoffmann, M. R., and S. D. Boyce, Catalytic autooxidation of aqueous sulfur dioxide in relationship to atmospheric systems, in Trace Atmospheric Constituents: Properties, Transformations, and Fates, edited by S. E. Schwartz, pp. 147-172, John Wiley, New York, 1983.

Hoffmann, M. R., and J. O. Edwards, Kinetics of the oxidation of sulfite by hydrogen peroxide in acidic solution, J. Phys. Chem., 79, 2096-2098, 1975.

Hoffmann, M. R., and D. J. Jacob, Kinetics and mechanism of the catalytic oxidation of dissolved $\mathrm{SO}_{2}$ in atmospheric droplets: Free radical, polar and photoassisted pathways, in $\mathrm{SO}_{3} \mathrm{NO}, \mathrm{NO}_{2}$ Oxidation Mechanisms: Atmospheric Considerations, edited by J. G. Calvert, pp. 101-172, Butterworth, Stoneham, Mass., 1984.

Jacob, D. J., and M. R. Hoffmann, A dynamic model for the production of $\mathrm{H}^{+}, \mathrm{NO}_{3}^{-}$, and $\mathrm{SO}_{4}^{2-}$ in urban fog, J. Geophys. Res., 88, 6611-6621, 1983 .

Jacob, D. J., J. M. Waldman, J. W. Munger, and M. R. Hoffmann, Chemical composition of fogwater collected along the California coast, Environ. Sci. Technol., 19, 730-736, 1985.

Jacob, D. J., J. M. Waldman, J. W. Munger, and M. R. Hoffmann, The $\mathrm{H}_{2} \mathrm{SO}_{4}-\mathrm{HNO}_{3}-\mathrm{NH}_{3}$ system at high humidities and in fogs, 2, Comparison of field data with thermodynamic calculations, J. Geophys. Res., 91, 1089-1096, 1986.

Junge, C. E., The modification of aerosol size distribution in the atmosphere, contract-Da 91-591-EVC 2979, U.S. Army, 1964.

Kawamura, K., and I. R. Kaplan, Organic compounds in rainwater, in Organic Chemistry of the Atmosphere, edited by L. D. Hansen and D. J. Eatough, pp. 233-284, CRC Press, Boca Raton, Fla., 1991.

Kolber, Z. S., R. T. Barber, K. H. Coale, S. E. Fitzwater, R. M. Greene, K. S. Johnson, S. Lindley, and P. G. Falkowski, Iron limitation of phytoplankton photosynthesis in the equatorial Pacific Ocean, $\mathrm{Na}$ ture, 371, 145-149, 1994.

Kopcewicz, B., and M. Kopcewicz, Mossbauer study of iron-containing atmospheric aerosols, Struct. Chem., 2, 303-312, 1991.

Kopcewicz, B., and M. Kopcewicz, Seasonal variations of iron concentration in atmospheric aerosols, Hyperfine Interact., 71, 1457-1460, 1992.

Lacroix, S., Étude de quelques complexes et composés peu soluble des ions: $\mathrm{Al}^{3+}, \mathrm{Ga}^{3+}, \mathrm{In}^{3+}$, Ann. Chim., 4, 5-27, 1949.

Ligocki, M. P., L. G. Salmon, T. Fall, M. C. Jone, W. W. Nazaroff, and G. R. Cass, Characteristics of airborne particles inside southern California museums, Atmos. Environ., 27(5), 697-711, 1993.

Martin, J. H., and R. M. Gordon, Northeast Pacific iron distributions in relation to phytoplankton productivity, Deep Sea Res., 35, 177196,1988

Martin, J. H., K. H. Coale, K. S. Johnson, S. E. Fitzwater, R. M. Gordon, S. J. Tanner, C. N. Hunter, V. A. Elrod, and J. L. Nowicki, Testing the iron hypothesis in ecosystems of the equatorial Pacific Ocean, Nature, 371, 123-129, 1994.

McArdle, J. V., and M. R. Hoffmann, Kinetics and mechanism of the oxidation of aquated sulfur dioxide by hydrogen peroxide at low $\mathrm{pH}$, J. Phys. Chem., 87, 5425-5429, 1983.

Millero, F. J., and S. Sotolongo, The oxidation of $\mathrm{Fe}(\mathrm{II})$ with $\mathrm{H}_{2} \mathrm{O}_{2}$ in seawater, Geochim. Cosmochim. Acta, 53, 1867-1873, 1989. 
Munger, J. W., The chemical composition of fogs and clouds in southern California, Ph. D. thesis, Calif. Inst. of Technol., Pasadena, 1989.

Munger, J. W., J. M. Waldman, D. J. Jacob, and M. R. Hoffmann, Fogwater chemistry in an urban atmosphere, J. Geophys. Res., 88, 5109-5121, 1983.

Munger, J. W., J. J. Collett, B. J. Daube, and M. R. Hoffmann, Chemical composition of coastal stratus clouds: Dependence on droplet size and distance from the coast, Atmos. Environ., 23, 2305-2320, 1989.

Patterson, C. C., and D. M. Settle, The reduction of orders of magnitude errors in lead analysis of biological materials and natural waters by evaluating and controlling the extent and sources of industrial lead contamination introduced during sampling, collecting, handling and analysis, Natl. Bur. of Stand., Spec. Publ., 422, 321-351, 1976.

Pehkonen, S. O., R. L. Siefert, Y. Erel, S. Webb, and M. R. Hoffmann, Photoreduction of iron oxyhydroxides in the presence of important atmospheric organic compounds, Environ. Sci. Technol., 27, 20562062, 1993.

Pehkonen, S. O., R. L. Siefert, and M. R. Hoffmann, Photoreduction of iron oxyhydroxides and the photooxidation of halogenated acetic acids, Environ. Sci. Technol., 29, 1215-1222, 1995.

Price, N. M., B. A. Ahner, and F. M. M. Morel, The equatorial Pacific Ocean-Grazer controlled phytoplankton populations in an iron limited ecosystem, Limnol. Oceanogr., 39, 520-534, 1994.

Rosenthal, J., T. E. Battalino, H. Hendon, and V. R. Noonkester, Marine/Continental History of Aerosols at San Nicholas Island, Pac. Missile Test Cent , Point Mugu, Calif., 1979.

Sakugawa, H., I. R. Kaplan, W. Tsai, and Y. Cohen, Atmospheric hydrogen peroxide, Environ. Sci. Technol., 24, 1452-1462, 1990.

Schroeder, W. H., M. Dobson, D. M. Kane, and N. D. Johnson, Toxic trace elements associated with airborne particulate matter: A review, J. Air Pollut. Control Assoc., 37, 1267-1285, 1987.

Schwarzenbach, R. P., P. M. Gschwend, and D. M. Imboden, Environmental Organic Chemistry, John Wiley, New York, 1993.

Seinfeld, J. H., Atmospheric Chemistry and Physics of Air Pollution, 738 pp., John Wiley, New York, 1986.

Siefert, R. L., S. O. Pehkonen, Y. Erel, and M. R. Hoffmann, Iron photochemistry of aqueous suspensions of ambient aerosol with added organic acids, Geochim. Cosmochim. Acta, 58, 3271-3279, 1994.

Smith, R. M., and A. E. Martell, Critical Stability Constants, Plenum, New York, 1974.
Spokes, L. J., T. D. Jickells, and B. Lim, Solubilisation of aerosol trace metals by cloud processing: A laboratory study, Geochim. Cosmochim. Acta, 58, 3281-3287, 1994.

Stookey, L. L., Ferrozine-A new spectrophotometric reagent for iron, Anal. Chem., 42, 119-781, 1970.

Taylor, S. R., and S. M. McLennan, The Continental Crust: Its Composition and Evolution, pp. 9-52, Blackwell Sci., Cambridge, Mass., 1985.

Thompson, A. M., The oxidizing capacity of the Earth's atmosphere: Probable past and future changes, Science, 256, 1157-1165, 1992.

Waldman, J. M., J. W. Munger, D. J. Jacob, R. C. Flagan, J. J. Morgan, and M. R. Hoffmann, The chemical composition of acid fog, Science, $218,677-680,1982$.

Wehrli, B., Redox reactions of metal ions at mineral surfaces, in Aquatic Chemical Kinetics, edited by W. Stumm, pp. 311-336, WileyIntersci., New York, 1990.

Westall, J. C., J. L. Zachary, and F. M. M. Morel, MINEQL, a computer program for the calculation of chemical equilibrium composition of aqueous solutions, Tech. Note 18, Dep. of Civil Eng., Mass. Inst. of Technol., Cambridge, Mass., 1976.

Zhu, X. R., J. M. Prospero, F. J. Millero, D. L. Savoie, and G. W. Brass, The solubility of ferric iron in marine mineral aerosol solutions at ambient relative humidities, Mar. Chem., 38, 91-107, 1992.

Zhu, X. R., J. M. Prospero, D. L. Savoie, F. J. Millero, R. G. Zika, and E. S. Saltzman, Photoreduction of iron(III) in marine mineral aerosol solutions, J. Geophys. Res., 98, 9039-9046, 1993.

Zhuang. G.. Z. Yi, R. A. Duce, and P. R. Brown, The chemistry of iron in marine aerosols, Global Biogeochem. Cycles, 7, 711, 1992a.

Zhuang, G., Z. Yi, R. A. Duce, and P. R. Brown, Link between iron and sulfur cycles suggested by detection of $\mathrm{Fe}(\mathrm{II})$ in remote marine aerosols, Nature, 355, 537-539, $1992 \mathrm{~b}$.

Zuo, Y., and J. Hoigné, Formation of hydrogen peroxide and depletion of oxalic acid in atmospheric water by photolysis of iron(III)-oxalato compounds, Environ. Sci. Technol., 26, 1014-1022, 1992.

M. R. Hoffmann (corresponding author), R. L. Siefert, and S. M. Webb, Environmental Engineering Science, W. M. Keck Laboratories, California Institute of Technology, Mail Code 138-78, $391 \mathrm{~S}$. Hollingston Avenue, Pasadena, CA 91125. (e-mail: mrh@cco.caltech.edu)

(Received July 20, 1995; revised January 5, 1996; accepted February 27, 1996.) 